\title{
Kimya Öğretmen Adaylarının Değerlendirmeye Bakış Açılarındaki Değişimin
}

\section{İncelenmesi}

\section{Nurcan TURAN-OLUK*, Funda EKİCİ**, Sinem GENÇER ${ }^{* * *}$ ve Hüseyin AKKUŞ ${ }^{* * * *}$}

Öz: Bu çalışmanın amacı, kimya öğretmen adaylarının değerlendirmeye ilişkin bakış açılarını tespit etmek ve bu bakış açılarının özel öğretim yöntemleri-II dersi sonucundaki değişimini incelemektir. Çalışma 13 kimya öğretmen adayı ile yürütüldü. Öğretmen adaylarının değerlendirmeye ilişkin bakış açılarını belirlemek için yedi adet açık uçlu sorudan oluşan bir test veri toplama aracı olarak kullanıldı. Çalışmanın bulgularına göre özel öğretim yöntemleriII dersi sonucunda kimya öğretmen adaylarının değerlendirmeye ilişkin bakış açılarında değişimler ve çeşitlilikler tespit edildi. Araştırmada; çalışma başlangıcında "hangi amaçlarla değerlendirme yapılmalıdır?” sorusuna katılımcıların neredeyse tamamından değerlendirme, anlama ve performans düzeyini belirlemek için "sonuç değerlendirme" amacıyla yapılmalı cevabı alınırken çalışma sonucunda "sonuç değerlendirme" yanında "teşhis değerlendirme" ve "süreç değerlendirme” amacıyla da değerlendirme yapılabileceği fikirlerine dönüştüğü tespit edildi. Benzer şekilde çalışma başlangıcında "sadece konu sonu ve ders sonunda değerlendirme yapılmalıdır" fikri, "dersin her anında değerlendirme" yapılabileceği fikrine dönüştü. Ayrıca değerlendirmenin sadece bilişsel kazanımları değil ilgi, tutum, motivasyon gibi duyuşsal kazanımları da kapsaması ve öğrencilere verilecek geri bildirimin bireysel ve motive edici olması gerektiğini düşündükleri tespit edildi.

Anahtar Kelimeler: Kimya eğitimi, kimya öğretmen adayı, değerlendirmeye bakış açıları

\footnotetext{
* Arş. Gör. Dr., Gazi Üniversitesi, Gazi Eğitim Fakültesi, Matematik ve Fen Bilimleri Eğitimi Bölümü, Email:nurcanturan@gazi.edu.tr Orcid No: 0000-0002-5430-4507.

**Arş. Gör. Dr., Gazi Üniversitesi, Gazi Eğitim Fakültesi, Matematik ve Fen Bilimleri Eğitimi Bölümü, Email:fundaekici@gazi.edu.tr Orcid No: 0000-0001-7534-368X.

***Arş. Gör. Dr., Gazi Üniversitesi, Gazi Eğitim Fakültesi, Matematik ve Fen Bilimleri Eğitimi Bölümü, Email:sinemuner@gazi.edu.tr Orcid No: 0000-0001-9902-7534.

***** Doç. Dr., Gazi Üniversitesi, Gazi Eğitim Fakültesi, Matematik ve Fen Bilimleri Eğitimi Bölümü, Email:akkus@gazi.edu.tr Orcid No: 0000-0001-8636-1074.
}

\begin{tabular}{lll}
\hline Gönderim:31.05.2019 Kabul:11.10.2019 $\quad$ Yayın: 25.11.2019 & Ka
\end{tabular}




\title{
Examination of the Changes in the Pre-service Chemistry Teachers' Perspectives on
}

\section{Assessment}

\begin{abstract}
The aim of this study is to determine pre-service teachers' perspectives on assessment and to investigate the change in their perspectives after the course, Chemistry Teaching Methods-II. The study was carried out with 13 pre-service chemistry teachers. In order to determine their perspectives on assessment, a test consisting of seven open-ended questions was used to collect data. The results revealed the changes in their perspectives on assessment as a result of the Chemistry Teaching Methods-II course. At the beginning of the study, almost all of the participants, in response to the question, "What is the purpose of assessment?" answered that assessment should be summative to detect the level of understanding and performance. However, they realized that ideas that assessment can also be diagnostic and formative at the end of the study. Similarly, the idea that assessment is done only at the end of a topic or lesson, which was determined at the beginning of the study, transformed into the idea that assessment can be done anytime. The participants realize that assessment should involve not only cognitive objectives, but also affective objectives such as interest, attitude or motivation, and that the feedback provided to students should be individual and motivating.
\end{abstract}

Keywords: Chemistry education, pre-service teacher of chemistry, perspectives on assessment 


\section{Giriş}

Bir öğretmenin, hem öğrenci öğrenmesini hem de öğrenci gelişimini anlamlı ve faydalı bir şekilde değerlendirebilmesi için neye odaklanması gerektiğini bilmeye ihtiyacı vardır (Edwards, 2013). Öğrencileri değerlendirip onlarla ilgili bir yargıya varmak, öğretimle ilgili kararlar almak, öğrencinin anlamasını ve düşünme becerilerini geliştirmek öğretmen tarafından yapılan değerlendirmenin temel amaçlarını oluşturmaktadır. Doğru bir amaç için doğru zamanda uygun değerlendirme tekniklerini kullanarak değerlendirme yapabilmek öğretmen açısından zordur (Friedrichsen, Lankford, Brown, Pareja, Volkman ve Abell, 2007). Bu nedenle öğrenme-öğretme sürecinin ve etkili bir öğretimin ayrılmaz bir parçası olan değerlendirme süreci, öğrenci öğrenmesini düzenlemede öğretmene yol göstermektedir (Edwards, 2013; Tacoshi ve Fernandez, 2014). Aynı zamanda öğrenci öğrenmesini değerlendirme becerisi, bir öğretmenin sahip olması gereken en önemli becerilerden biridir (Izci ve Caliskan, 2017). Sınıf içinde etkili bir şekilde kullanılan değerlendirme uygulamaları, öğrenci öğrenmesini değiştirme gücüne sahiptir (Graham, 2005). Çünkü değerlendirme süreci kazanımların belirlenmesi ile başlamakta ve bu kazanımların hangilerinin ne ölçüde kazanıldığının belirlenmesi ile bitmektedir (Gelbal ve Kelecioğlu, 2007; Linn ve Gronlund, 1995). Diğer bir ifade ile bir öğretmen açısından iyi bir değerlendirme, iyi ölçme araçları geliştirme ve uygulama ile değil, öğrencilerin ne öğrenmesini istediğine karar verdiği an başlamaktadır (McConnell ve Doolittle, 2012). Değerlendirme süreci, öğrenci başarısını ölçmek için birçok teknik kullanmayı gerektirir ancak değerlendirme kavramı bu tekniklerin toplamından çok daha fazlasını ifade etmektedir (Linn ve Gronlund, 1995). Değerlendirme süreci hem değerlendiren hem de değerlendirilen için mesajlar içermektedir (Edwards, 2013).

Shulman (1986) pedagojik alan bilgisini (PAB), bir öğretmenin sahip olduğu bilgi türlerinin bir boyutu olarak açıklamış ve konuyu temsil edebilen analojileri, çizimleri, örnekleri, açıklamaları ve gösterimleri içeren; konuyu öğrenciler için anlaşılır hale getirme yolları olarak tanımlanmıştır. Bu tanımlamada değerlendirme bilgisine yer verilmezken, değerlendirme bilgisine Tamir (1988) tarafından PAB'ın bir alt boyutu olarak yer verilmiştir. Magnusson, Krajcik ve Borko (1999) ise fen öğretimi için önerdikleri PAB modelinde; fen öğretimine yönelik oryantasyon, öğretim programı bilgisi, öğretim stratejileri bilgisi, öğrenci bilgisi ve değerlendirme bilgisi olmak üzere PAB'ın beş bileşenden oluştuğunu ifade etmişlerdir. PAB'ın bileşenlerinden biri olarak tanımlanan ve bir öğretmenin sahip olması gereken bilgi türlerinden biri olan değerlendirme bilgisi; bir öğretmenin neyi, nasıl ve neden 
değerlendirdiğini kapsamaktadır (Magnusson, Krajcik, ve Borko, 1999). Bir öğretmenin değerlendirme bilgisi; öğrenci önbilgilerini açığa çıkarmak, öğrenci ilerlemesini ölçmek, öğretimle ilgili kararlar vermek ve öğrenci öğrenmesini belirlemede güvenilir bir bilgi elde etmek için öğretmenin kullandığg stratejilerden oluşmaktadır (Friedrichsen vd., 2007). Ayrıca öğretmenin ölçme-değerlendirme tekniklerinden hangilerini kullanacağını, hangi amaç doğrultusunda değerlendirme yapacağını, bir konu için hangi ölçme-değerlendirme tekniklerinin daha uygun olacağını belirleyebilmesi ile de ilgilidir (Şen ve Nakiboğlu, 2018).

Bir öğretmenin; öğrencinin anlamasını ve becerisini arttırmak, ayrıca kendi öğretimini geliştirmek amacıyla değerlendirmeyi nasıl kullanabileceğini bilmesi gerekmektedir (Grossman, Schoenfeld ve Lee, 2005). Değerlendirme bilgisi, öğretim sürecinin ne kadar verimli geçtiğini belirlemek adına da oldukça önemlidir (Şen ve Nakiboğlu, 2018). Diğer taraftan değerlendirme sürecinin etkili bir şekilde yönetilememesi, geçerli ve güvenilir bir değerlendirme yapmayı önlemekte ve öğretimle ilgili yanlış kararlar verilmesine sebep olmaktadır (DeLuca ve Klinger, 2010). Son y1llarda öğrenme sürecinde sonuçtan ziyade sürecin ön plana çıktığı görülmektedir. Bu yaklaşım, hem öğrenme-öğretme etkinliklerine hem de değerlendirme uygulamalarına olumlu bir şekilde yansımaktadır. Değerlendirme yaklaşımındaki değişime paralel olarak alanyazında da; öğretmenlerin ve öğretmen adaylarının farklılaşan bu yaklaşımı değerlendirme yaparken ne ölçüde hayata geçirdikleri, değerlendirme ile ilgili fikirleri ve kullandıkları değerlendirme teknikleri araştırılmaya başlanmıştır (Nazlıçiçek ve Akarsu, 2008). Alanyazındaki çalışmalar incelendiğinde, bu çalışmalarda genellikle öğretmen veya öğretmen adaylarının değerlendirmeye ilişkin görüşlerinin (Taşdemir ve Taşdemir, 2016), bilgilerinin (Nazlıçiçek ve Akarsu, 2008; Şen ve Nakiboğlu, 2018; Tacoshi ve Fernandez, 2014), ölçme-değerlendirme okuryazarlıklarının (Karaman ve Şahin, 2017; Tünkler ve Güven, 2019), özyeterliklerinin (Tatar ve Buldur, 2013) ve değerlendirme bilgisinin geliştirilmesinin (Bektas, Ekiz, Tuysuz, Kutucu, Tarkin ve Uzuntiryaki-Kondakci, 2013; Karaman ve Şahin, 2017; Mertler, 2009; Uğurlu ve Akkoç, 2011) araştırıldığı görülmektedir. $\mathrm{Bu}$ çalışmalardan birinde, Şen ve Nakiboğlu (2018) tarafindan deneyimli kimya öğretmenlerinin fiziksel ve kimyasal değişimler konusundaki değerlendirme bilgisi incelenmiştir. Araştırma sonucunda kimya öğretmenlerinin değerlendirme bilgilerinin geleneksel yaklaşımla uyumlu olduğu belirlenmiştir. Benzer bir şekilde Şad ve Göktaş (2013) tarafından yapılan çalışmada da eğitim fakültesinde görev yapan öğretim elemanlarının alternatif değerlendirme yaklaşımlarını yeterince benimsemedikleri tespit edilmiştir. 
Nazlıçiçek ve Akarsu (2008) kimya, fizik ve matematik öğretmenlerinin değerlendirme bilgilerini ve yaklaşımlarını inceledikleri çalışma sonucunda öğretmenlerin geleneksel değerlendirme tekniklerine ilişkin bilgilerinin yüksek, alternatif değerlendirme tekniklerine ilişsin bilgilerinin ise düşük olduğunu tespit etmişlerdir. Tacoshi ve Fernandez (2014) kimya öğretmenlerinin değerlendirme bilgilerini incelemişlerdir. Çalışmada öğrencilerin üst düzey düşünme becerilerini değerlendirme, değerlendirme sonuçlarını eğitim-öğretimi geliştirme ve öğrenme sürecini düzenleme amacıyla kullanma açılarından kimya öğretmenlerinin yetersiz bilgiye sahip oldukları belirlenmiştir. Izci ve Caliskan (2017) ölçme-değerlendirme dersi sonucunda farklı disiplinlerde öğrenim gören öğretmen adaylarının değerlendirmeye yönelik kavramlarında bir değişim olup olmadığını incelemişlerdir. Çalışma sonucunda, öğretmen adaylarının değerlendirmeyle ilgili kavramlarında anlamlı bir farklılık olmadığı belirlenmiş ve bu kavramların gelişiminin oldukça karmaşık olduğu ve deneyim, kültür gibi faktörlerden etkilendiği ifade edilmiştir. Tatar ve Buldur (2013) fen bilgisi öğretmen adaylarının alternatif değerlendirme yaklaşımlarını kullanmaya yönelik özyeterliklerinin arttırmak için bir öğretim programı uygulamışlardır. Uygulanan program sonucunda katılımcıların alternatif değerlendirme yaklaşımlarına yönelik bilgilerinin ve bu yaklaşımları kullanmaya yönelik özyeterliklerinin geliştiği tespit edilmiştir. Karaman ve Şahin (2017) ise yaptıkları çalışmada fen bilimleri öğretmen adaylarının ölçme-değerlendirme okuryazarlıklarını mikroöğretim yoluyla geliştirmeye çalışmışlardır. Çalışma sonucunda mikroöğretim uygulamalarının öğretmen adaylarının değerlendirmeye ilişkin bilgi, beceri ve tutumlarının gelişimine katkı sağladığını tespit etmişlerdir. Benzer bir şekilde Tünkler ve Güven (2019) de sosyal bilgiler öğretmen adaylarının tamamlayıcı ölçme-değerlendirme tekniklerine yönelik okuryazarlıklarına mikroöğretim uygulamasının etkisini incelemişlerdir ve bu uygulamaların öğretmen adaylarının tamamlayıcı ölçme-değerlendirme tekniklerine yönelik okuryazarlık düzeylerinin gelişimine katkı sağladığını belirlemişlerdir. Bektas vd. (2013) tarafından yürütülen çalışmada ise kimya öğretmen adaylarının bilimin doğası konusundaki PAB'larının gelişimi öğretmenlik uygulaması dersi kapsamında incelenmiştir. Çalışma sonucunda kimya öğretmen adaylarının çoğunda değerlendirme bilgisinin gelişim göstermediği belirlenmiştir. Mertler (2009) öğretmenlere sınıf içi değerlendirmeye yönelik verilen bir eğitimin öğretmenlerin değerlendirmeye yönelik görüşleri üzerindeki etkisini incelemiştir. Çalışmada verilen eğitim sonucunda öğretmenlerin değerlendirmeyle ilgili kavramlar hakkındaki bilgilerinin geliştiği ve öğrenci performansını değerlendirme konusunda öğretmenlerin daha 
özgüvenli hissetmeye başladıkları belirlenmiştir. Benzer bir şekilde, Uğurlu ve Akkoç (2011) da öğretmen adaylarının PAB'ın ölçme-değerlendirme bileşeninde gösterdikleri gelişmeyi incelemiş ve verilen eğitim sonucunda katılımcıların değerlendirmenin amacına yönelik görüşlerinde kavramsal olarak zenginleşme olduğunu tespit etmiştir. Graham (2005) İngilizce öğretmen adaylarının değerlendirme bilgilerinin ve uygulamalarının mentorluk sonucunda değişimini incelemiştir. Çalışmada katılımcıların başlangıçta hem anlamlı öğrenme kazanımlarının nasıl oluşturulacağı hem de bu kazanımlara ulaşılıp ulaşılmadığının nasıl değerlendireceği konularında bilgilerinin yetersiz olduğu tespit edilmiştir. Ayrıca mentorluk etkisiyle değerlendirmenin ne olduğunu açık bir şekilde anlama, hedef ve yapılan değerlendirmelerin uyumlu olması gerektiğinin farkına varma ve biçimlendirici (formatif) değerlendirmenin etkililiğini fark etme konularında katılımcıların değerlendirme uygulamalarında değişimler meydana geldiği belirlenmiştir. Katılımcılar değerlendirme uygulamalarında meydana gelen değişimlerin birçok faktöre bağlı olduğunu ve bu faktörler en etkili olanın mentor öğretmenler olduğunu ifade etmişlerdir. Lew ve Nelson (2016) mesleğinin ilk yıllarındaki öğretmenlerin yaşadıkları zorlukları incelemiş ve bu zorluklardan birinin de sınıf içi değerlendirmeler olduğunu tespit etmişlerdir. Ayrıca bu çalışmadaki öğretmenlerin, nitelikli değerlendirme uygulamaları hakkında yeterli bir eğitim almadıklarını düşündükleri de belirlenmiştir. Taşdemir ve Taşdemir (2016) öğretmen adaylarının okullardaki ölçme ve değerlendirme uygulamalarının nasıl olduğuna ilişkin görüşlerini metaforlar aracılığı ile incelemişlerdir. Katılımcıların ölçme ve değerlendirmenin, insan vücudu gibi, iyi hazırlanmış ve iyi işleyen bir sistem olması gerektiğini düşündükleri belirlenmiştir.

Değerlendirme yaklaşımları ve bu yaklaşımların uygun bir şekilde kullanılması konularında yeterlik sahibi öğretmenler yetiştirmek eğitim-öğretimin kalitesinin arttırılmasında bir gereklilik olarak karşımıza çıkmaktadır (Volante ve Fazio, 2007). Öğretmen yetiştirme programları, öğretmen adaylarının öğrenme ve değerlendirme süreçlerine ilişkin yaklaşımları üzerinde büyük rol oynamaktadır (Hancock ve Gallard, 2004). Ayrıca bu programlar, ölçme-değerlendirme okuryazarı ve meslek hayatları boyunca değerlendirme hakkında öğrenmeye açık öğretmenler yetiştirilmesi açısından da büyük önem taşımaktadır (DeLuca, Chavez ve Cao, 2013). Değerlendirme süreci; öğretmenlik mesleğinin en önemli noktalarından biridir (Mertler, 2009). Buna karşın, bu süreç mesleğinin ilk yıllarındaki öğretmenlerin sınıflarında karşı karşıya kaldıkları en zor süreçlerden birini oluşturmaktadır (Lew ve Nelson, 2016). Değerlendirme sürecinde eksikler olan bir öğretimin hedeflenen 
amaçlara ulaşabilmesi mümkün değildir (Karaman ve Şahin, 2017). Bu zorlu süreçle başa çıkabilmeleri için öğretmen adaylarının değerlendirmeyle ilgili deneyimlerinin arttırılması ve mesleki gelişim firsatları ile karşı karşıya kalmaları gerekmektedir (Tatar ve Buldur, 2013). Bu nedenle öğretmen adaylarının değerlendirmeye yönelik bakış açılarının incelenmesi ve öğretmen yetiştirme programında yer alan derslerin bu bakış açıları üzerindeki etkisinin araştırılması oldukça büyük bir önem taşımaktadır. Öğretmen adaylarının değerlendirmeye bakış açılarının belirlenmesi ve geliştirilmesi; eğitim-öğretimin ayrılmaz bir parçası olan değerlendirme sürecindeki aksakların giderilebilmesi açısından da oldukça önemlidir. Ancak kimya eğitimiyle ilgili alanyazın incelendiğinde, mevcut çalışmalarda değerlendirmenin bu bağlamda çok fazla ele alınmadığı görülmektedir. Ayrıca öğretmen yetiştirme programlarında yer alan derslerin, öğretmen adaylarının değerlendirmeye bakış açısına etkisinin de genellikle araştırılmadığı söylenebilir. Alanyazındaki çalışmalardan farklı olarak bu çalışmada kimya öğretmen adaylarının değerlendirme kavramı ile ilgili amaç, değerlendirmeye ayrılan süre, geri bildirim gibi birçok değişkenle ilgili görüşleri ve özel öğretim yöntemleri-II (ÖÖY-II) dersinin bu görüşlere etkisi ele alındı. Alanyazına bu anlamda katkı sağlayacağı düşünülen bu çalışmada, geleceğin kimya öğretmenleri olan kimya öğretmen adaylarının değerlendirmeye bakış açıları ve bu bakış açılarının ÖÖY-II dersi sonucundaki değişimi incelendi.

\section{Yöntem}

Araştırma Modeli: Kimya öğretmen adaylarının “değerlendirme” kavramına ilişkin bakış açıları tespit edilip, ÖÖY-II dersi boyunca katılımcıların değerlendirmeye ilişkin bakış açılarındaki değişim incelendiğinden, bu çalışma bir durum çalışmasıdır. Durum çalışmasında küçük bir örneklemden toplanan veriler belirli bir bağlamda detaylı bir şekilde incelenir (Cresswell, 2013; Zainal, 2007). Bu çalışmada incelenen durum kimya öğretmen adaylarının değerlendirmeye bakış açılarıdır.

Katılımcılar: Çalışma bir devlet üniversitesinin kimya öğretmenliği programında 3. sınıfta öğrenim gören 13 öğretmen adayının (dokuz kadın, dört erkek) gönüllü katılımı ile yürütüldü. Katılımcılar, seçkisiz olmayan örnekleme yöntemlerinden biri olan uygun örnekleme ile çalışmaya dahil edildi. Uygun örnekleme, kolay ulaşılabilir bireylerin örnekleme dahil edildiği örnekleme yöntemidir (Fraenkel ve Wallen, 2006). Katılımcıların yaşları 20-22 yaş arasında değişmektedir. Katılımcıların ÖÖY-II dersini aldıkları dönem öncesindeki genel not ortalamaları ise 4'lük sistem üzerinden 1,74 ile 3,75 arasında değişmektedir. 
Bu çalışma ÖÖY-II dersi kapsamında, bu dersi alan tüm öğretmen adaylarıyla, yürütüldü. ÖÖY-II dersi kapsamında öğretmen adayları özel öğretim yöntemleri-I dersinde tanıtımı yapılan öğretim yöntem ve teknikleri ile ilgili ders planları hazırlayıp o planları uygularlar. Ders anlatımlarından sonra öğretmen adaylarına öğretimleriyle ilgili geri bildirim verilir. Öğretmen adayı geri bildirimler doğrultusunda ders planında ilgili değişiklikleri yapar ve tekrar ders anlatımını gerçekleştirir. Bu çalışmaya katılan kimya öğretmen adayları ÖÖY-II dersinden önce öğrenme öğretme kuram ve yaklaşımları, özel öğretim yöntemleri-I ve ölçmedeğerlendirme gibi alan eğitimi ve meslek bilgisi derslerini almış durumdaydılar. Dolayısıyla katılımcıların hem öğretim yöntem ve teknikleri hem de ölçme değerlendirme yöntem ve teknikleri konusunda bilgisi olduğu söylenebilir.

Çalışmanın başında katılımcılar, ders kapsamında bir çalışma yürütüleceği, araştırmacıların rolü, isterlerse herhangi bir anda çalışmadan ayrılabilecekleri ve çalışmanın bulgularının raporlaştırılacağı konusunda bilgilendirildi ve onayları alındı. Bilimsel çalışmalarda etik kurallara göre katılımcıların isimlerinin gizli tutulması ve katılımcılara takma isim verilmesi önemlidir (Patton, 2014). Bu çalışmada da katılımcıların isimlerinin gizli tutulması için tüm katılımcılara takma isimler verildi ve doğrudan alıntılarda bu takma isimler kullanıldı.

Araştırma Süreci: Çalışma daha önce belirtildiği gibi ÖÖY-II dersi kapsamında, haftada dört saat olmak üzere 14 hafta boyunca yürütüldü. Çalışmanın başında, katılımcıların değerlendirme kavramı ile ilgili görüşlerini belirlemek için yedi adet açık uçlu sorudan oluşan bir test ön test olarak uygulandı ve katılımcıların görüşlerini yazılı olarak açıklamaları istendi. Daha sonra katılımcilar öğretim programında yer alan 9., 10., 11. ve 12. sınıf kimya konularından bir tanesini kura ile seçtiler. Seçtikleri bu konuda kendi istedikleri bir kazanımla ilgili 40 dakikalık bir ders saati için ders planı hazırladılar. Hazırladıkları bu ders planıyla, kendilerinin öğretmen, akranlarının ise öğrenci rolü üstlendiği bir sınıfta bu dersi yürüttüler. Plan hazırlama ve uygulama aşamasında araştırmacılar katılımcılara herhangi bir müdahalede bulunmadı. Çalışmada yer alan araştırmacılar çalışma süresince hem eğitmen olarak görev aldı hem de derslerde gözlemci olarak yer aldı. Dört araştırmacı da kimya eğitimi alanında doktoralarını tamamlamış olup, lisans ve lisansüstü düzeyde alan eğitimi dersi vermektedirler.

Araştırmacılar tarafından 13 katılımcının tamamının birer kez ders anlatımından sonra katılımcılara, kimya eğitiminde yaygın olarak kullanılan öğretim yöntem ve teknikleri ile PAB'ın tüm bileşenlerini ayrıntılı olarak içeren altı saatlik bir hatırlatma eğitimi verildi. Ayrıca 
ölçme değerlendirme konusunda soruların bilişsel düzeyi ve değerlendirme kavramı ile ilgili iki saatlik bir hatırlatma eğitimi de verildi.

Daha sonra katılımcıların başlangıçta planlayarak yürüttükleri derslerden bir tanesi seçilerek, bu derste "değerlendirmenin hangi bileşenlerinin yer aldığı”, "öğretmen adayının süreç ve sonuç değerlendirme olarak sınıfa yönelttiği/yöneltebileceği soruların bilişsel düzeyi” ve "iyi bir değerlendirme için bu derste neler olması gerektiği”" gibi konular katılımcılarla tartışıldı. Bu süreçte araştırmacılar teşhis, süreç ve sonuç değerlendirmede kullanılabilecek alternatif örnekler vererek, eksiklikler ve nelerin yapılması gerektiği ile ilgili yönlendirmeler yaptılar. Ayrıca araştırmacılar hem öğretim yöntem ve teknikleriyle ilgili hem de değerlendirme süreci ile ilgili somut örnekleri öğrenci sunumları üzerinde gösterdiler.

Eğitim sürecinin tamamlanmasının ardından katılımcılar başlangıçta seçtikleri konuda, farklı kazanımlar için ikişer kez daha ders planı hazırlayarak ders anlattılar. Bu süreçte araştırmacılar, tüm katılımcılara planlarında yer alan değerlendirme bileşenleri açısından hem plan aşamasında hem de öğretim uygulaması sırasında yaptıkları değerlendirmelerle ilgili geribildirim verdiler. Tüm katılımcılar ikişer defa ders anlattıktan sonra yedi adet açık uçlu sorudan oluşan test, son test olarak uygulandı ve katılımcıların değerlendirme kavramına ilişkin görüşlerindeki değişimler belirlendi.

Veri Toplama Araçları ve Analizi: Katılımcıların değerlendirmeye ilişkin bakış açılarını belirlemek amacıyla Rowntree (2015)'nin değerlendirme ile ilgili sorduğu sorular esas alınarak yedi adet açık uçlu sorudan oluşan bir test hazırlandı. Hazırlanan bu testin kapsam geçerliği ilgili olarak, kimya eğitimi alanında uzman iki eğitimciden uzman görüşü alındı. Bu test, katılımcılara ön-test ve son-test olmak üzere iki kez uygulandı. Araştırmada kullanılan test aşağıdaki soruları içermektedir.

1) Değerlendirme sizin için ne anlama gelmektedir?

Bir kimya öğretmeni;

2) Ne zaman değerlendirme yapmalıdır? Açıklayınız.

3) Hangi amaç/amaçlarla değerlendirme yapmalıdır? Açıklayınız.

4) Neyi değerlendirmelidir? Açıklayınız.

5) Değerlendirmeye ne kadar süre ayırmalıdır? Açıklayınız.

6) Değerlendirme sonucu geri bildirim vermeli midir? Evet, ise bu geri bildirim nasıl olmalidir?

7) Hangi değerlendirme yöntem/tekniklerini kullanmalıdır? Açıklayınız. 
Katılımcıların sorulara verdikleri cevaplar yazılı olarak alındı. Bu yazılı cevapların analizinde içerik analizi kullanıldı. Bulgular doğrudan alıntı ve frekanslarla sunuldu. Verilerin analizinde açık kodlama kullanıldı. Yazılı ifadeler öncelikle bir araştırmacı tarafından içerik analizine tabi tutularak ham kod ve kategoriler elde edildi. Aynı işlemler ikinci bir araştırmacı tarafindan rastgele seçilen, ham verilerin \%40’1 üzerinde yapıldı ve birinci analizci ile ikinci analizci arasında ön test analizi için ortalama uyum puanı \%90 (1. soru: \%100, 2. soru: \%93, 3. soru: \%85, 4. soru: 83 , 5. soru: $\% 100$, 6. soru: \%75, 7. soru: \%91) olarak hesapland1. Son test analizi için ortalama uyum puan1 $\% 92$ (1. soru: $\% 75$, 2. soru: $\% 100$, 3. soru: $\% 100$, 4. soru: 90, 5. soru: \%88, 6. soru: \%90, 7. soru: \%100) olarak hesapland1. Kod ve kategori isimlerindeki tüm anlaşmazlıklar giderildikten sonra üçüncü araştırmacı diğer iki araştırmacı tarafından önerilen kod ve kategori isimlerinin uygunluğunu ve birleştirilmesi gereken kategoriler olup olmadığını belirlemek amacıyla hem ön test hem son test verileri üzerinde inceleme yaptı. Birinci ve ikinci analizci ile üçüncü analizci arasında ön test analizi için ortalama uyum puanı \%94; son test analizi için ortalama uyum puanı \%95 olarak hesaplandı. Analizciler arasındaki uyuşmazlıklar (Ör: daha önce iki farklı kategori olarak önerilen "kazanımlara ulaşı1ma düzeyini belirleme" ve "konunun ne kadar öğrenildiğini belirleme" kategorileri birleştirildi) tartışmalar yoluyla giderildi. Üç farklı analizcinin incelemeleri ile son hali verilen kod ve kategori isimleri dikkate alınarak birinci analizci tarafından analiz tüm katılımcılar için baştan tekrarlanarak bulguların güvenirliği arttırıldı.

\section{Bulgular}

Çalışmanın bulguları veri toplama aracındaki sorular bazında açıklanarak aşağıda sunulmaktadır. Ayrıca bulgular doğrudan alıntılarla desteklenmiştir.

\section{Değerlendirmenin Anlamı}

Katılımcıların "Değerlendirme sizin için ne anlama gelmektedir?” sorusuna verdikleri cevaplardan elde edilen kategoriler ve frekanslar Şekil 1’de görülmektedir. 
Değerlendirme sizin için ne anlama gelmektedir?

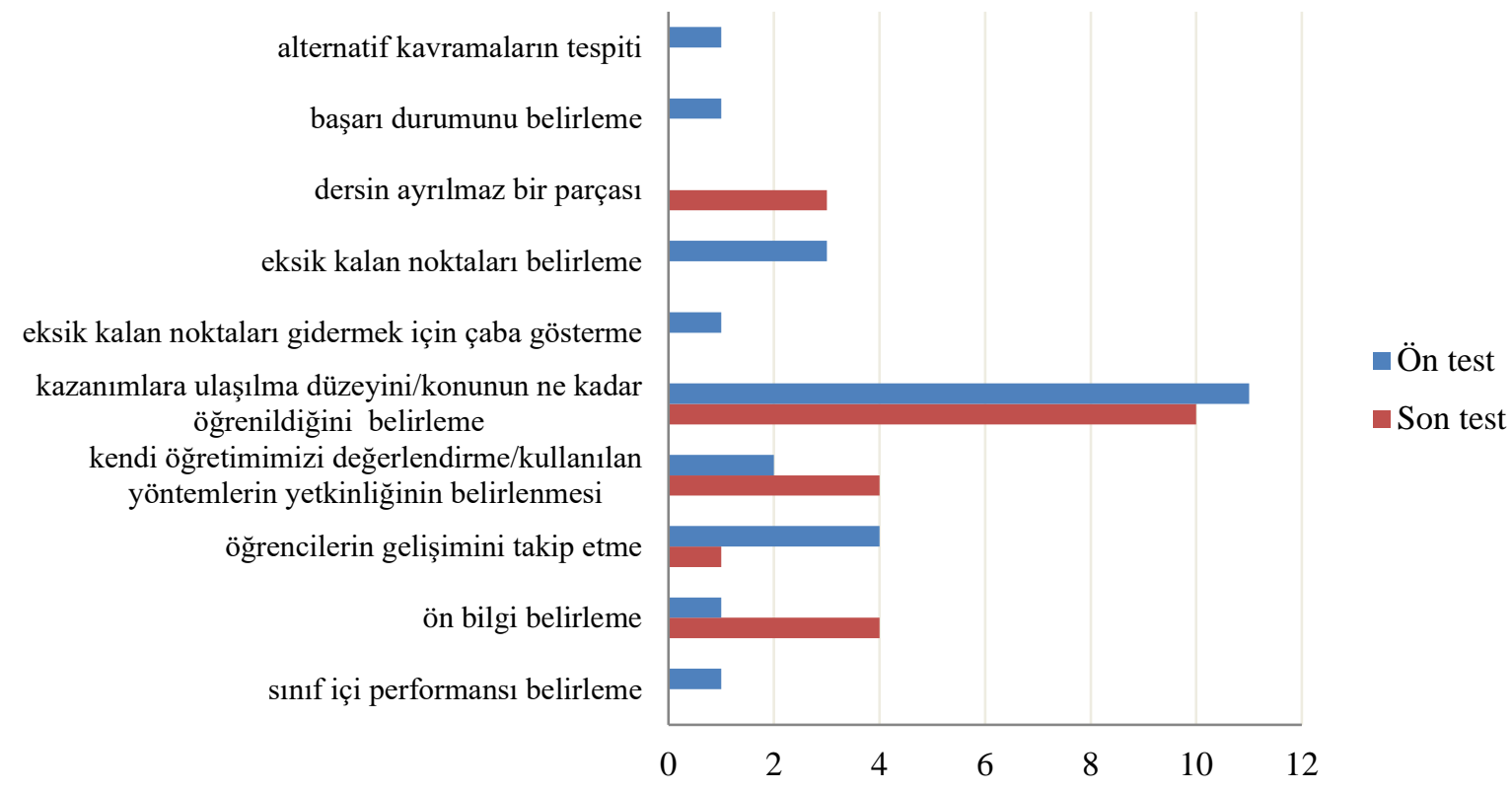

Şekil 1. Katılımcıların "Değerlendirme sizin için ne anlama gelmektedir?” sorusuna verdikleri cevapların frekansları

Şekil 1 incelendiğinde, ön testin sonuçlarına göre katılımcıların çoğunun değerlendirmenin "kazanımlara ulaşılma düzeyini/konunun ne kadar öğrenildiğini belirleme” anlamına geldiğini ifade ettikleri görülmektedir. "Öğrencilerin gelişimini takip etme” en sık ifade edilen ikinci cevap olurken bunu "eksik kalan noktaları belirleme" izlemektedir. Son testin cevapları incelendiğinde ise katılımcıların en çok söyledikleri ifadenin, ön testin sonuçlarındaki gibi "kazanımlara ulaşılma düzeyini/konunun ne kadar öğrenildiğini belirleme” olduğu görülmektedir. Ön test ve son teste verilen cevaplar bir bütün olarak ele alındığında değerlendirmenin “dersin ayrılmaz bir parçası” olduğu ön teste verilen cevaplar arasında olmayıp, sadece son teste verilen cevaplar arasında yer almaktadır. Ayrıca verilen cevaplardan "kendi öğretimimizi değerlendirme/kullanılan yöntemlerin yetkinliğinin belirlenmesi” ve "ön bilgi belirleme” kategorisindeki artış da oldukça dikkat çekmektedir. Katılımcılardan ikisinin "Değerlendirme sizin için ne anlama gelmektedir?" sorusuna ilişkin ifadeleri aşağıda verilmektedir.

Ada: "Bir öğretmenin bir süreç sonunda belirlediği amaç ve kazanımların istediği şekilde ögrrenilip ögrenilmediğini kontrol etmesi. ” (Ön test)

Ada: "Değgerlendirme ĕgitimin vazgeçilmez bir parçasıdır. Öğrencilerin neler ögrendiklerini, ne kadar ögrendiklerini ve nasıl ögrrendiklerini bize gösterir. Süreçte 
herhangi bir hata varsa iyileştirmeyi sağlar. Ders boyunca değerlendirme olmalıdır." (Son test)

Demet: "Ben kazanım anlatacă̆ım, benim amacım öğrencinin bu kazanımı kazanmasıdır. Bu amaçla değerlendirme yapılmalıdır. Hedefe ulaşıldığının bir nevi kontrolüdür.” (Ön test)

Demet: "Değerlendirme bir öğrencinin konuyla ilgili eksiklikleri var mı, konu anlatıldiğında yeterince ögrenme să̆landı mı, konu anlatımında kullanılan yöntem ve teknikler yeterli mi gibi sorulara cevap vermek için yapllması gereken önemli bir araçtır." (Son test)

\section{Değerlendirme Ne Zaman Yapılmalıdır?}

Katılımcıların "Bir kimya öğretmeni ne zaman değerlendirme yapmalıdır?” sorusuna verdikleri cevaplardan elde edilen kategoriler ve frekanslar Şekil 2'de sunulmaktadır.

Bir kimya öğretmeni ne zaman değerlendirme yapmalıdır?

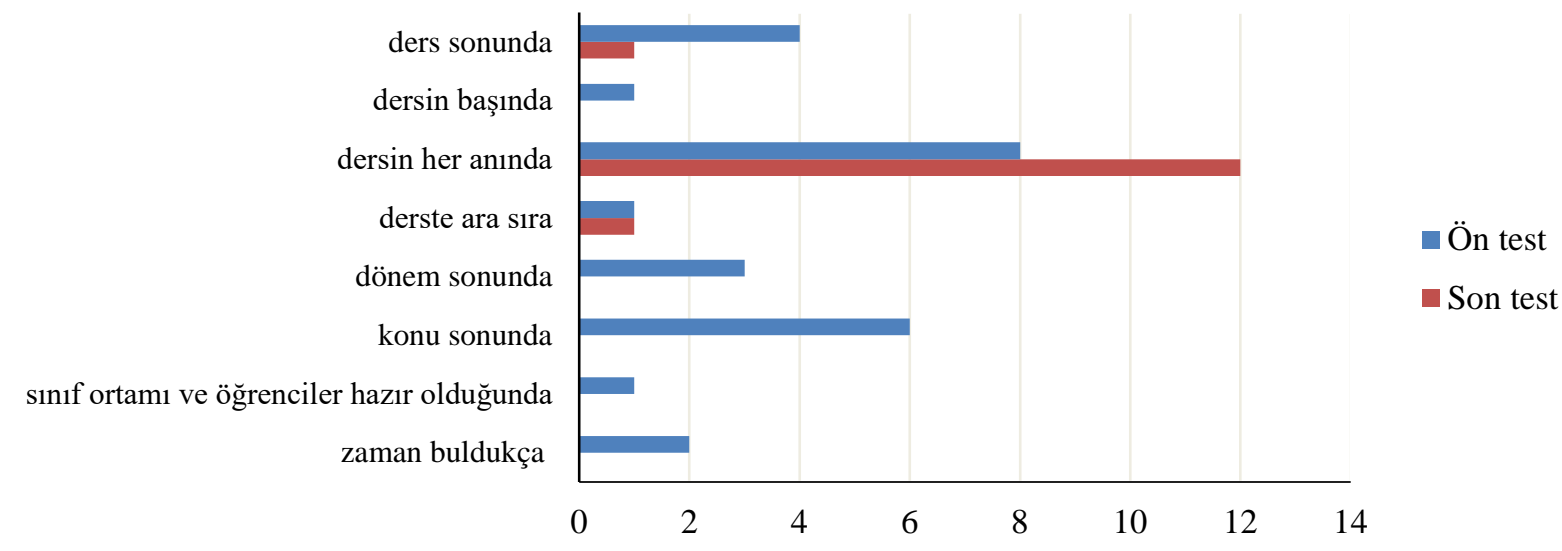

Şekil 2. Katılımcıların “Bir kimya öğretmeni ne zaman değerlendirme yapmalıdır?” sorusuna verdikleri cevapların frekansları

Şekil 2'ye göre, ön testte katılımcıların, değerlendirme “dersin sonunda”, “dönem sonunda", "sınıf ortamı ve öğrenciler hazır olduğunda" ve "zaman buldukça" yapılmalı ifadeleri dikkat çekmektedir. Son testte ise katılımcıların büyük çoğunluğunun görüşlerinin değiştiği ve değerlendirme “dersin her anında olmalıdır” görüşünü benimsedikleri görülmektedir. $\mathrm{Bu}$ sonuca dayanarak katılımcıların değerlendirmeye bakış açılarının gelenekselden yapılandırıcı görüşe kaydığı ve başlangıçta değerlendirmeyi yalnız sonuç değerlendirme olarak görürken, sonunda süreç değerlendirmeyi göz önünde bulundurarak dersin her anında olması gerektiği fikrini ortaya koydukları söylenebilir. Katılımcıların "Bir 
kimya öğretmeni ne zaman değerlendirme yapmalıdır?” sorusuna ilişkin ön testteki ve son testteki ifadelerinden örnekler aşağıda verilmektedir.

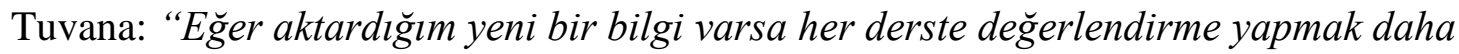
iyi olacaktır. Fakat değerlendirme için sürem kalmamışsa yapmadan da geçilebilir.” (Ön test)

Tuvana: "Kesinlikle her derste değerlendirme yapmalıdır. Bu ders aralarında da olabilir, ders sonunda da olabilir. Çünkü değerlendirilmesi olmayan ders boşa geçmiş demektir. ” (Son test)

Serkan: "Her derste değerlendirme yapılacak diye bir şart yoktur.” (Ön test)

Serkan: "Her derste değerlendirme olmalıdır. Değerlendirme demek sadece puan verdiğimiz sorular değil sınıf içerisinde yönelttiğimiz tüm soruları kapsamaktadır. Hiç soru sorulmayan bir ders yoktur.” (Son test)

\section{Değerlendirmenin Amacı}

Katılımcıların "Bir kimya öğretmeni hangi amaçlarla değerlendirme yapmalıdır?" sorusuna verdikleri cevapların analizinden elde edilen bulgular Şekil 3’te görülmektedir. Katılımcıların ifadelerinden elde edilen kategoriler, teşhis değerlendirme, süreç değerlendirme ve sonuç değerlendirme temaları altında toplanarak sunuldu. 
Bir kimya öğretmeni hangi amaçlarla değerlendirme yapmalıdır?

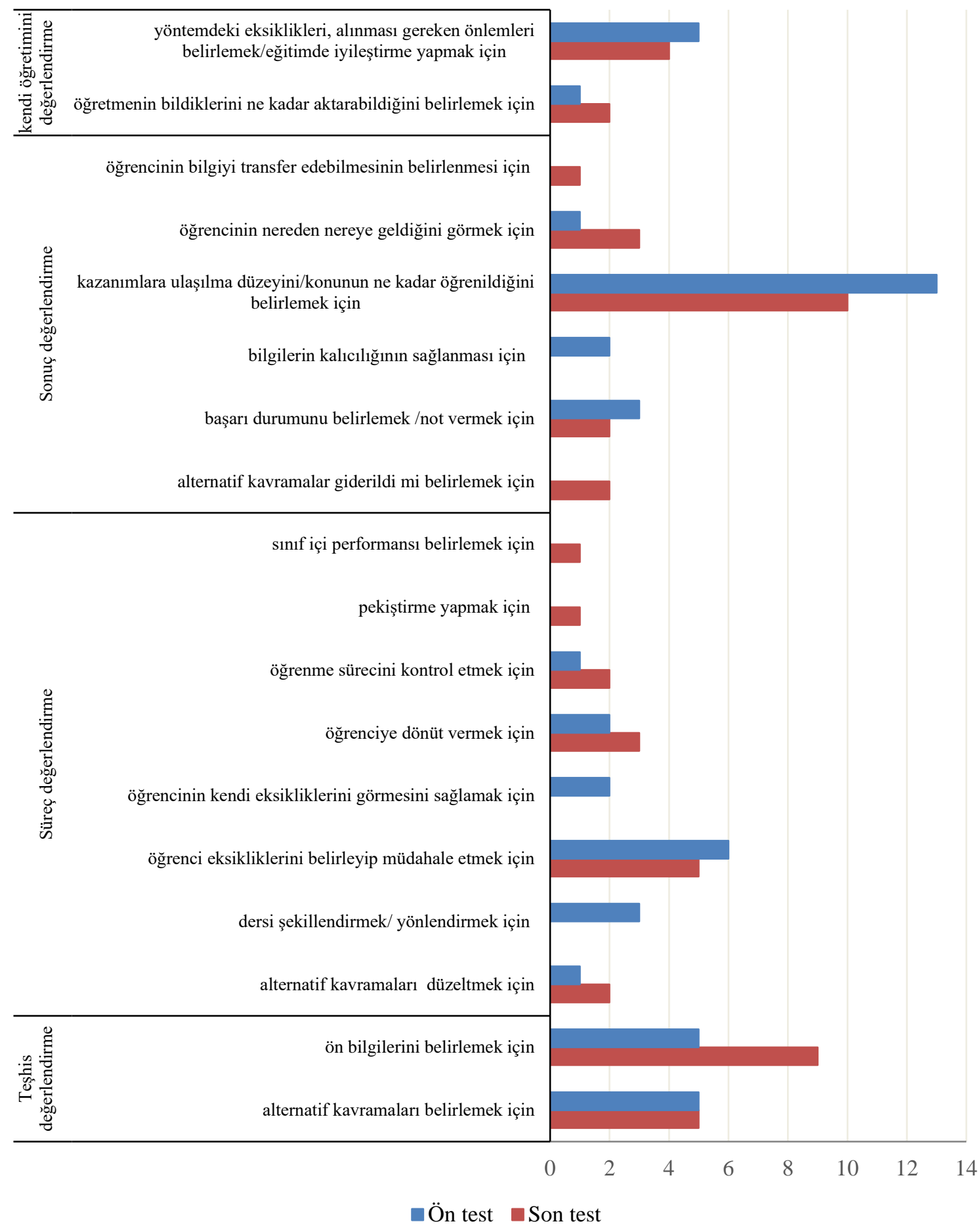

Şekil 3. Katılımcıların “Bir kimya öğretmeni hangi amaçlarla değerlendirme yapmalıdır?” sorusuna verdikleri cevapların frekansları

Şekil 3 incelendiğinde, ön testte verilen cevaplardan katılımcıların neredeyse tamamının değerlendirmenin "sonuç değerlendirme" amacıyla yapılacağını ifade ettiği görülmektedir. Son testin cevapları incelendiğinde ise, ön testte katılımcıların hemen hemen 
tamamı değerlendirmenin "sonuç değerlendirme" amaçlı yapılacağını ifade etmişken, son testte bunu ifade eden katılımcı sayısında azalma görüldü. Bunun yanında "teşhis değerlendirme" amacıyla değerlendirme yapılacağını belirten katılımcı sayısı, aynı durumu ifade eden ön testteki katılımcı sayısına göre oldukça artış göstermektedir. Şekil 3, biraz daha detaylı incelendiğinde ön teste verilen cevapların çoğunun son teste verilen cevaplar arasında yer aldığı, buna ek olarak son testte yeni cevaplar da bulunduğu belirlendi. "Süreç değerlendirme" amaçlı yapılan değerlendirmeye dâhil edilen "sınıf içi performansı belirlemek" ve "pekiştirme yapmak" ifadeleri son teste verilen yeni cevaplar arasındadır. Ayrıca "sonuç değerlendirme" amaçlı yapılan değerlendirmeye dâhil edilen "öğrencinin bilgiyi transfer edebilmesinin belirlenmesi” ve "alternatif kavramalar giderildi mi belirlemek" ifadeleri yine son teste verilen yeni cevaplar arasında yer aldı. Katılımcıların "Bir kimya öğretmeni hangi amaçlarla değerlendirme yapmalıdır?” sorusu için ön test ve son testte yaptığı açıklamalardan örnekler aşağıda verilmektedir.

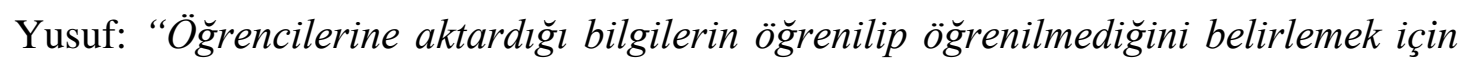
değerlendirme yapmalıdır." (Ön test)

Yusuf: “Öğretmen öğrencinin zihnini kontrol etmek için değerlendirme yapmalıdır. Öğretmen, öğrencinin bilgisini anlamlandırabilmesi için dĕgerlendirme yapmalıdır. Öğrenci bilgiyi yanlış biçimde öğrenmiş olabilir ya da yanlış kavramalarla birlikte ögrenmiş olabilir. Bu yanlış kavramaları ve bilgi eksikliklerini giderebilmek için ögretmen değerlendirme yapmalıdır. Öğretmen, öğrencinin bilgisini pekiştirmek için değerlendirme yapmalıdır. Çünkü pekiştirilmeyen bilgi beş dakika önce öğrenilse bile unutulur. Öğretmen ögrenciye not vermek için de değerlendirme yapmalıdır... ” (Son test)

Kumru: "Öğrencinin verilen kazanımı ögrenip öğrenmediğini kontrol etmek için değerlendirme yapmalıdır." (Ön test)

Kumru: "Öğrencinin konuyu ne kadar öğrendiğini, eksik kaldı̆̆ noktaları, yanlış kavradı̆̆ kavramları belirlemek için değerlendirme yapmalıdır. ” (Son test)

\section{Ne Değerlendirilmelidir?}

Katılımcıların "Bir kimya öğretmeni neyi değerlendirmelidir?" sorusuna verdikleri cevaplar analiz edilerek elde edilen kategori ve frekanslar Şekil 4'te verilmektedir. 
Bir kimya öğretmeni neyi değerlendirmelidir?

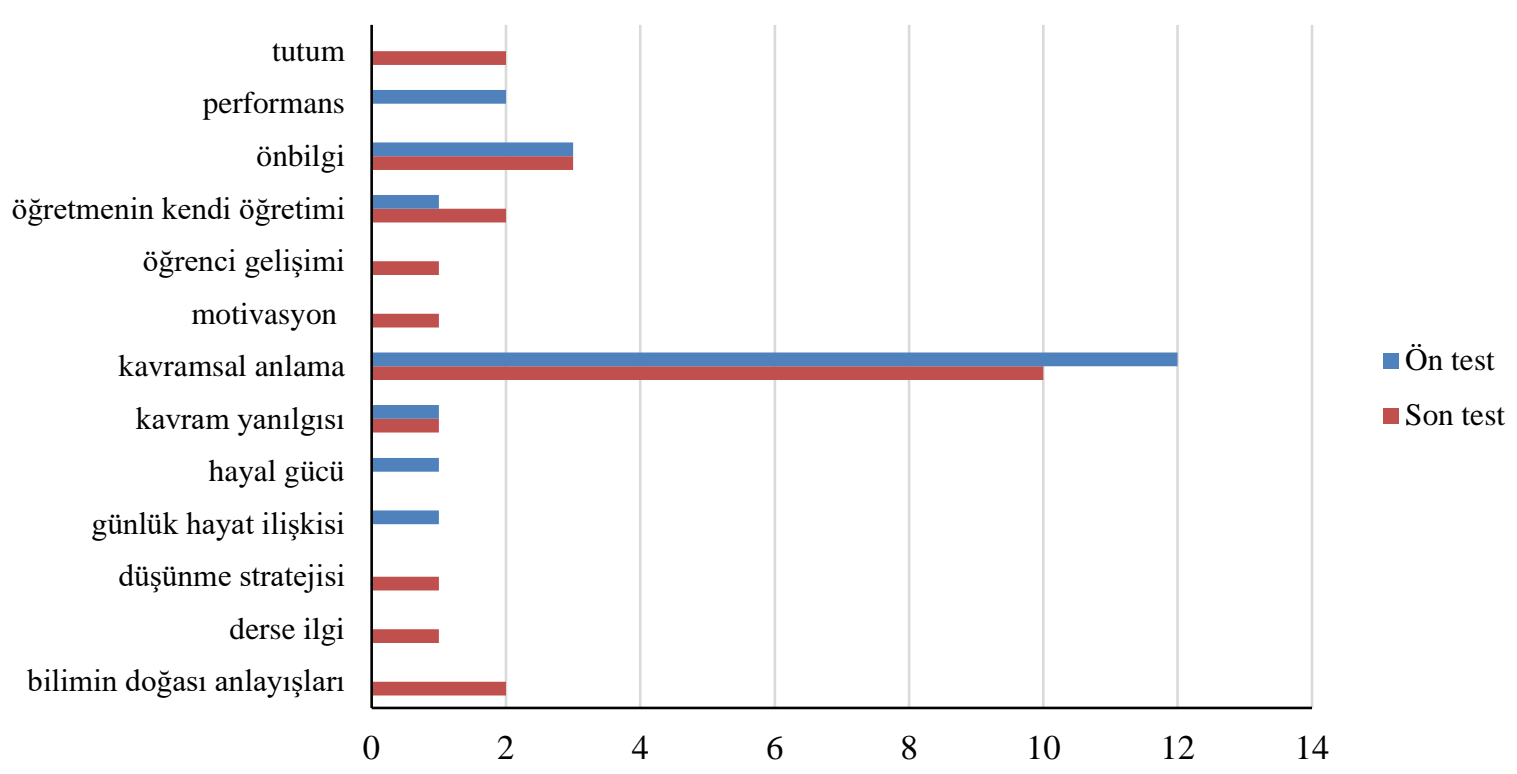

Şekil 4. Katılımcıların "Bir kimya öğretmeni neyi değerlendirmelidir?" sorusuna verdikleri cevapların frekansları

Şekil 4 incelendiğinde katılımcıların ön testte, bir öğretmen "kavramsal anlama"yı değerlendirmelidir görüşünü benimsedikleri görülmektedir. Bir kimya öğretmeninin değerlendirmesi gereken “önbilgi”, “performans”, “öğretmenin kendi öğretimi”, "kavram yanılgısı", "hayal gücü” ve "günlük hayat ilişkisi” ise ön testte nadiren karşılaşılan cevaplar arasındadır. Son testin cevapları incelendiğinde ise, ön testte belirtilen cevapların birçoğunun son teste verilen cevaplar arasında yer aldığ belirlendi. Örneğin, “tutum”, “öğrenci gelişimi”, “motivasyon”, “düşünme stratejisi”, “derse ilgi”, "bilimin doğası anlayışları" gibi bir öğretmenin değerlendirmesi gereken ancak çoğu zaman göz ardı edilen diğer boyutların son testte katılımcılar tarafından ifade edildiği belirlendi. Katılımcıların “Bir kimya öğretmeni neyi değerlendirmelidir?” sorusu için ön test ve son testte yaptığı açıklamalardan örnekler aşağıda yer almaktadır.

Ada: “Öğrencilerdeki değişsimi, ilk durumdan son duruma açı̆̆a çıkan farkı değerlendirmeli. Belirlenen hedef ve kazanımlar öğrencilerde oluşup oluşmadığına bakılmalı." (Ön test)

Ada: “Öğrenci önbilgilerini, öğrenci hal ve tutumlarını, öğrenci motivasyonunu, kavramsal anlamayı, bilimin doğasını anlamayı dĕgerlendirmelidir. Öğretmen kendisinin belirlediği amaçları, öğretim programında bulunan kazanımların gerçekleşip gerçekleşmediğini değerlendirmelidir. ” (Son test) 
Ece: "Bir öğretmen öğrenciye verilmek istenen kazanımı ne derece ne kadar kazandı̆̆ını kontrol etmek için değerlendirme yapmalıdır." (Ön test)

Ece: “Öğrencinin ders öncesinde neler bildiklerini değerlendirmelidir. Ders esnasında o günkü verilmek istenen konuyu ögreniyorlar mı öğrenmiyorlar mı? Bunu değerlendirmelidir. Ders sonunda ise o günkü konunun nerelerde eksik ögrenildiğini, öğrenilmediğini görmek adına değerlendirme yapmalıdır. ” (Son test)

\section{Değerlendirmeye Ayrılacak Süre}

Katılımcıların "Bir kimya öğretmeni değerlendirmeye ne kadar süre ayırmalıdır?" sorusuna verdikleri cevaplardan elde edilen kategori ve frekanslar Şekil 5 'te görülmektedir.

Değerlendirmeye ne kadar süre ayırmalıdır?

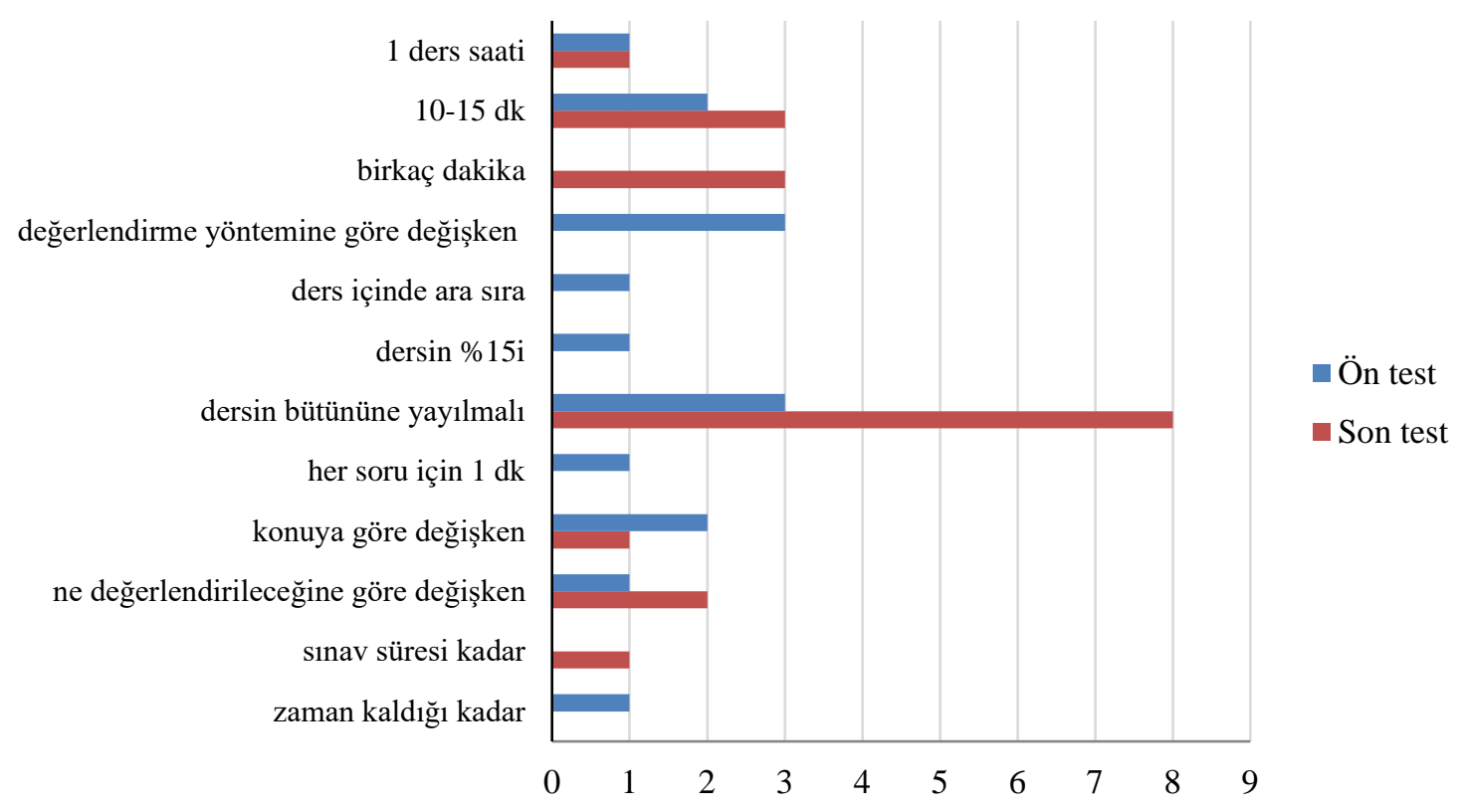

Şekil 5. Katılımcıların "Bir kimya öğretmeni değerlendirmeye ne kadar süre ayırmalıdır?" sorusuna verdikleri cevapların frekansları

Katılımcıların ön testteki ifadeleri incelendiğinde neredeyse tamamının “değerlendirme"yi dersten ayrı bir kavram olarak gördükleri ve değerlendirme için; "10-15 dakika", “dersin içinde ara sıra”, “dersin \%15'i”, "her soru için 1 dakika” gibi süreler önerdikleri görülmektedir. Hatta bir öğrencinin “zaman kaldığı kadar” ifadesi oldukça dikkat çekicidir. Son testin cevapları incelendiğinde ise değerlendirme "dersin bütününe yayılmalı" diyen katılımcı sayısındaki net artış dikkat çekmektedir. Katılımcıların "Bir kimya öğretmeni değerlendirmeye ne kadar süre ayırmalıdır?" sorusu için ön testte ve son testteki açıklamalarından örnekler aşağıda verilmektedir. 
Ayla: “Konular, etkinlikler, deneyler gibi faktörlerin sürelerine bağlı olabilir fakat her konu sonrası 15 dakika mutlaka harcanmalı diye düşünüyorum.” (Ön test)

Ayla: "Değerlendirme her basamakta olduğu için bütün ders süresi kadar değerlendirme olmalıdır." (Son test)

Şule: "Değerlendirmeye çok süre ayrılmamalıdır... Çünkü çok süre ayrılırsa işlenecek konu yetişmeyebilir." (Ön test)

Şule: “Belli bir süre ayrılmasına gerek yoktur. Çünkü dersin her anında değerlendirme yapılmalıdır." (Son test)

\section{Değerlendirmede Geri Bildirim}

Katılımcıların "Bir kimya öğretmeni değerlendirme sonucu geri bildirim vermeli midir? Evet, ise bu geri bildirim nasıl olmalıdır?” sorusuna verdikleri cevaplar analiz edilerek ulaşılan kategori ve frekanslar Şekil 6'da verilmektedir.

Değerlendirme sonucu geri bildirim verilmeli midir? Evet, ise bu geri bildirim nasil olmalıdır?

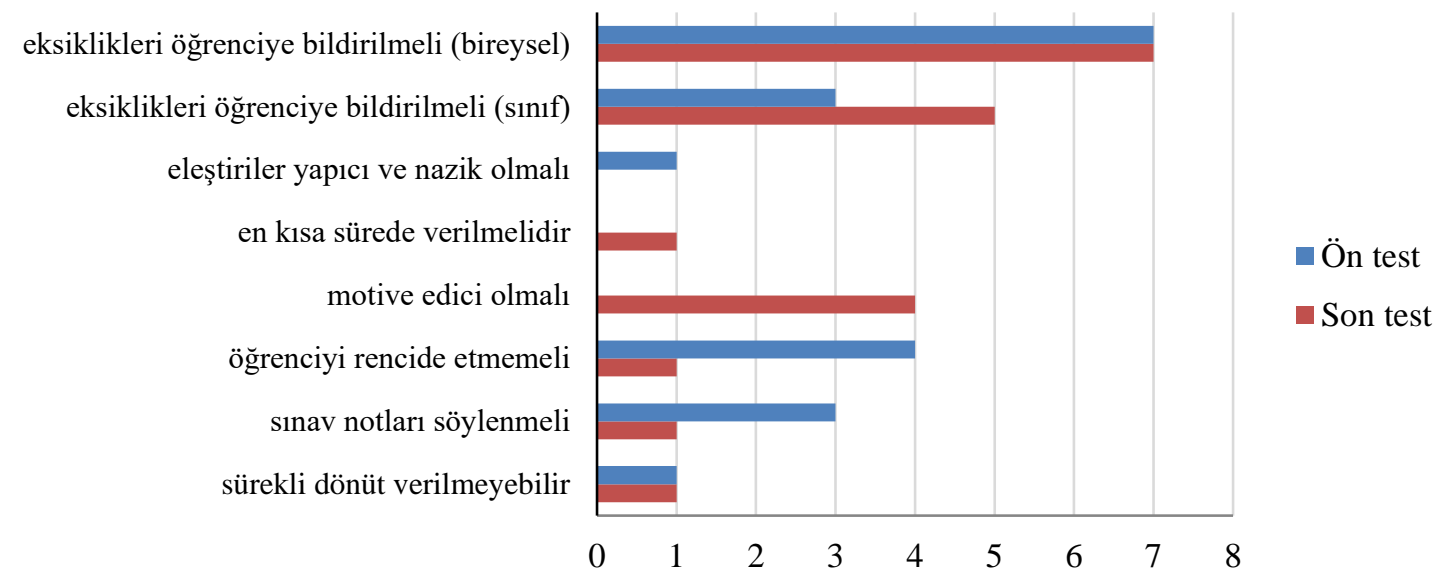

Şekil 6. Katılımcıların "Bir kimya öğretmeni değerlendirme sonucu geri bildirim vermeli midir? Evet, ise bu geri bildirim nasıl olmalıdır?" sorusuna verdikleri cevapların frekansları

Katılımciların tamamı hem ön testte hem de son testte geri bildirim verilmesi gerektiğini belirtmişlerdir. Ayrıca katılımcıların çoğunluğunun geri bildirimin bireysel verilmesi gerektiği konusunda da hemfikir olduğu görülmektedir. Ayrıca sınıfa toplu geri bildirim verilmesi gerektiği de son testte artış gösteren cevaplar arasında yer aldı. Geri bildirimin "en kısa sürede verilmesi” ve "motive edici olması" gerekliliği ise son testte belirlenen yeni cevaplardan olduğu belirlendi. Katılımcıların hem ön testte hem son testte geri bildirim verilmesi konusunda hemfikir olduğu görülmekle beraber, ön testte geri bildirimi daha çok sınav notlarının söylenmesi olarak gördükleri, son testte ise süreç içinde eksiklerin 
öğrencilere söylenmesi olarak algıladıkları söylenebilir. Katılımcıların "Bir kimya öğretmeni değerlendirme sonucu geri bildirim vermeli midir? Evet, ise bu geri bildirim nasil olmalıdır?” sorusuna ilişkin ön test ve son testteki ifadelerinden örnekler aşağıda verilmektedir.

Emre: “Her zaman değil... Dönem sonlarında veya ortalarındaki sınav sonuçları ögrenciler ile paylaşılmalıdır. ” (Ön test)

Emre: “Evet. Öğrenci ile birebir görüşerek geri bildirim verilmelidir.” (Son test)

Yusuf: "Geri dönüt verilebilir. Bu not şeklinde olabilir. Ya da öğrenci eksiklerini görmesini sağlayacak şekilde olabilir. Geri dönüt verirken öğrencinin hevesi kırılmamalıdır.” (Ön test)

Yusuf: “Öğrenciye geri dönüt verilmelidir. Öğretmen her ögrenciye bireysel olarak geri dönüt vermekte zorlanabilir. Ortak yanlış yapılan sorularda ögrencileri bir araya toplayabilir. O grubun yanlışlarını anlamalarını sağlayabilir.” (Son test)

Rüya: "Evet verilmelidir. Ö̆grenci öğrenme ortamından uzaklaşmadan müdahale edilmesi için verilmelidir” (Ön test)

Rüya: "Değerlendirme sonucu geri bildirim verilmelidir. Mesela ders sonunda yazılı bir değgerlendirme yapıldıysa dönütü kesinlikle olmalı ki ögrenci eksiğini bilsin, ona göre ögretmen veya başka bir takviye ile onu tamamlasin." (Son test)

\section{Değerlendirme Yöntem ve Teknikleri}

Katılımcıların "Bir kimya öğretmeni hangi değerlendirme yöntem/tekniklerini kullanmalıdır?” sorusuna verdikleri cevaplardan elde edilen bulgular Şekil 7'de görülmektedir. 
Hangi değerlendirme yöntem/tekniklerini kullanmalıdır?

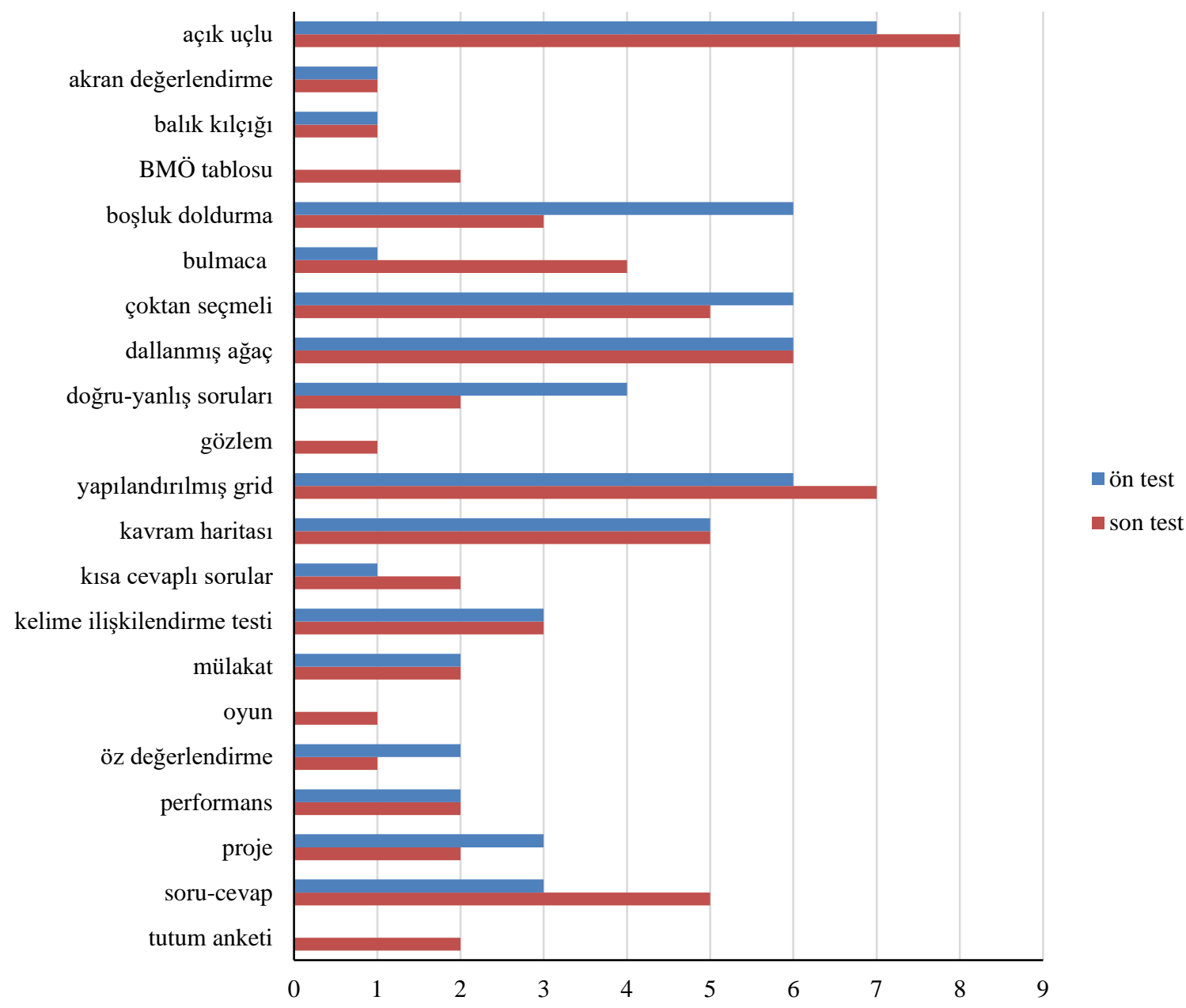

Şekil 7. Katılımcıların "Bir kimya öğretmeni hangi değerlendirme yöntem/tekniklerini kullanmalıdır?" sorusuna verdikleri cevapların frekansları

$\mathrm{Bu}$ bulgulara göre, katılımcıların ön teste verdikleri cevaplar arasında bir kimya öğretmeninin en çok kullanması gereken yöntem/tekniklerin açık uçlu sorular, boşluk doldurma, çoktan seçmeli sorular, tanılayıcı dallanmış ağaç, yapılandırılmış grid gibi yöntem/teknikler olduğu belirlendi. Kavram haritası, proje, soru-cevap, mülakat, kelime ilişkilendirme testi (KITT), balık kılçı̆̆ı gibi yöntem/teknikler ise tercih edilmesi gereken diğer yöntem/teknikler olarak tespit edildi. Son testin cevapları incelendiğinde ise ön testtekine benzer cevaplar olmakla birlikte, bildiklerim/ merak ettiklerim/öğrendiklerim (BMÖ) tablosu, gözlem, oyun ve tutum anketi gibi farklı değerlendirme yöntem/tekniklerinin de katılımcı cevaplarına eklendiği görülmektedir. Ön test ve son test bulguları birlikte değerlendirildiğinde, katılımcıların hem ön testte hem son testte hem alternatif hem geleneksel teknikler kullanılarak 
değerlendirme yapılması gerektiğini ifade ettikleri görülmektedir. Katılımcıların "Bir kimya öğretmeni hangi değerlendirme yöntem/tekniklerini kullanmalıdır?” sorusuna ilişkin ön test ve son testteki ifadelerinden örnekler aşağıda verilmektedir.

Ada: "Yazll, sözlü sinavlar yapllabilir. Farklı soru türlerine yer verilmelidir. Mülakatlar yapılabilir. Soru-cevap tekniği yapılabilir. Tartışma ortamları yaratılabilir." (Ön test)

Ada: “Ön bilgileri belirlemek için; soru-cevap, KWL [BMÖ]

Süreci değerlendirmek için; soru-cevap, oyun

Sonuç değerlendirme için; testler, klasik ve alternatif sorular, oyun” (Son test)

Nazlı: "Klasik ve alternatif değerlendirme yöntemleri bir arada kullanılmalıdır." (Ön test)

Nazlı: "Klasik dĕgerlendirme ve alternatif değerlendirme yöntemleri bir arada kullanılmalıdır. Değerlendirmenin amacı düşünülerek uygun yöntemler seçilmelidir." (Son test)

Fikret: “...Açık uçlu sorular, testler, yapılandırılmış grid, dallanmış ă̆aç, mülakat” (Ön test)

Fikret: “Kelime ilişkilendirme, soru-cevap, açık uçlu sorular, mülakat”" (Son test)

\section{Tartışma}

Kimya öğretmen adaylarının değerlendirmeye bakış açılarının incelendiği bu çalışmada ÖÖY-II dersi sonucunda öğretmen adaylarının bakış açılarında değişimler ve çeşitlilikler olduğu sonucuna ulaşıldı. ÖÖY-II dersinden önce katılımcılar tarafından genellikle kazanımlara ulaşma düzeyini gösteren anlama ve performans düzeyini belirlemek amacıyla düzey belirleme odaklı bir süreç olarak algılanan değerlendirmenin; dersten sonra katılımcılar için daha çeşitli anlamlar ifade etmeye başladığı görüldü. Başlangıçta değerlendirmeyi sadece düzey belirleme amaçlı "sonuç değerlendirme" yapmak amacıyla düşünen katılımcılar bulunmasına rağmen; son testte değerlendirmeyi dersin ayrılmaz bir parçası olarak gören, teşhis amaçlı ve kendi öğretim süreçlerini izleyerek öğrencilerin öğrenmelerini ve gelişimlerini görmek amacıyla da süreç değerlendirmeyi kullanmayı düşünen katılımcı sayısında artış olduğu belirlendi. Çalışmanın bu bulguları, Uğurlu ve Akkoç (2011) tarafından yürütülen çalışmanın bulguları ile benzerlik göstermektedir. 
Çalışmada ÖÖY-II dersinden sonra katılımcıların özellikle değerlendirme zamanı ile ilgili görüşlerinde belirgin bir değişim olduğunu söylemek mümkündür. Dersten önce değerlendirmenin "zaman bulundukça”, "konu sonu” veya "ders sonunda” yapılması gerektiğini düşünen katılımcılar, ÖÖY-II dersinden sonra değerlendirme sürecinin tüm ders sürecine yayılması gerektiğini ve dersin ayrılmaz bir parçası olduğunu ifade ettiler.

ÖÖY-II dersinden önce katılımcıların; değerlendirmenin sadece kaldı geçti gibi düzey belirlemek için "sonuç değerlendirme” amacıyla yapılacağını düşündükleri belirlendi. Bu durum geleneksel bakış açısında, öğrenci başarısının değerlendirilmesi, genellikle öğretim sürecinden ayrı ve daha çok ürüne ağırlık verecek bir şekilde ele alındığı (Gelbal ve Kelecioğlu, 2007) tespiti ile örtüşmektedir. Bu çalışmada da katılımcıların başlangıçta değerlendirmeyi daha geleneksel gördükleri, ÖÖY-II dersi sonunda ise değerlendirmenin farklı amaçlarla kullanılabileceğini anladıkları görülmektedir. Örneğin, teşhis değerlendirme amacıyla değerlendirme yapılması gerektiğini düşünen katılımcıların sayısında artış olduğu tespit edildi. Ayrıca bu ders kapsamında öğretim uygulamaları gerçekleştiren katılımcıların öğrenci önbilgilerinin açığa çıkarılmasında teşhis değerlendirmenin gerekliliği ile ilgili daha fazla farkındalığa sahip olduğunu söylemek mümkündür. Diğer bir deyişle, katılımcıların araştırma sürecinde aldıkları eğitim sayesinde değerlendirmenin amaçlarına yönelik farkındalıklarının arttığı görülmektedir. Bunun yanında katılımcıların, hem öğretim sürecini izleme ve düzenleme hem de öğrencilerinin öğrenme sürecindeki kavramsal anlamalarındaki değişim ve gelişimi görmek amacıyla da değerlendirme yapılabileceğini fark ettikleri söylenebilir. Çalışmanın bu bulgusu, kimyadan farklı bir disiplinde, Graham'ın (2005) mentorluk etkisi ile değerlendirme bilgisinin gelişimini incelediği çalışmanın bulguları ile benzerlik göstermektedir. Karaman ve Şahin (2017) ile Tünkler ve Güven (2019) tarafından yürütülen çalışmalarda da mikroöğretim uygulamalarının öğretmen adaylarının ölçme-değerlendirme okuryazarlıklarının gelişsimine katkı sağladığı tespit edilmiştir. Ancak bu çalışmanın sonuçları, Bektas vd. (2013) tarafından yürütülen çalışmada öğretmen adaylarının, öğretmenlik uygulaması dersi sonucunda, değerlendirme bilgisinde bir gelişim olmadığı sonuçları ile farklılık göstermektedir. Bu çalışmanın sonuçları, alanyazındaki diğer araştırmalarla birlikte değerlendirildiğinde; değerlendirme bilgisinin gelişimi ile ilgili farklı sonuçlara ulaşıldığı görülmektedir. Bu nedenle öğretmen adaylarının değerlendirmeyle ilgili gelişim göstermelerini sağlayan unsurların ileride yapılacak çalışmalarda daha detaylı incelenmesi önerilmektedir. 
Bir öğretmenin neyi değerlendirmesi gerektiğine ilişkin bulgular incelendiğinde; katılımcılar tarafından tüm süreç boyunca en çok ifade edilen noktanın "kavramsal anlama" olduğu görülmektedir. ÖÖY-II dersinden sonra ise katılımcıların sadece bilişsel kazanımları değil aynı zamanda ilgi, tutum, motivasyon gibi duyuşsal kazanımları da değerlendirmeyi düşündükleri belirlendi. $\mathrm{Bu}$ ders sayesinde katılımcıların duyuşsal kazanımların da değerlendirilmesi gerektiğinin farkına vardıkları söylenebilir. Kimya öğretim programında da ölçme ve değerlendirme yaklaşımında sadece bilişsel kazanımlar açısından yapılan ölçümlerin yeterli kabul edilemeyeceği belirtilmektedir (Milli Eğitim Bakanlığı [MEB], 2018).

Katılımcıların değerlendirmeye ayrılması gereken süreye ilişkin görüşlerinde ise net bir değişim olduğu görüldü. Katılımcılar tarafından ÖÖY-II dersi öncesinde değerlendirme için ayrılması gereken sürenin; konuya, ne değerlendirileceğine, değerlendirme yöntemine göre değişebileceği ve hatta değerlendirmenin dersin belirli bir yerinde zaman kalırsa yapılabileceği ifade edildi. Organisation for Economic Co-operation and Development (OECD) (2014) raporunda da öğretmenlerin değerlendirmeye ayırdıkları sürenin diğer eğitim-öğretim faaliyetlerine ayırdıkları süreye göre daha kısa olduğu belirtilmiştir. $\mathrm{Bu}$ çalışmada katılımcıların büyük çoğunluğu son testte değerlendirmenin tüm ders sürecine yayılması gerektiğini belirttiler. Sonuç olarak, ÖÖY-II dersi öncesinde katılımcıların değerlendirmeye ayrılan süre ile ilgili çok çeşitli görüşleri bulunurken, ÖÖY-II dersi sonrasında ise katılımcılar, bu sürenin dersin bütününe yayılması gerektiğiyle ilgili ortak bir görüş benimsemişlerdir.

Katılımcılar, ÖÖY-II dersi öncesinde ve sonrasında değerlendirme sonucu ile ilgili öğrencilere geri bildirim verilmesi gerektiği konusunda hemfikirdirler. Katılımcıların çoğu verilecek geri bildirimin bireysel olması gerektiğini düşünmektedir. Eğitimlerden önce, verilmesi gereken geri bildirimin niteliği ile ilgili detay vermeyen katılımcılar, eğitimlerden sonra ise geri bildirimin öğrenci açısından motive edici olması gerektiğini ifade ettiler. $\mathrm{Bu}$ çalışmanın sonuçları Metin ve Özmen (2010) tarafından yürütülen ve geri bildirimin motive edici olması gerektiğinin vurgulandığı çalışmanın sonuçları ile uyumludur. Geri bildirim öğrenci öğrenmesini kolaylaştırmakta, öğrenci motivasyonu arttırmakta ve öğrencilerin öz değerlendirme yapma becerisine katkı sağlamaktadır (Case, 2007). Ancak öğrenci gelişimine yardımcı olabilmesi için verilecek geri bildirimin yapıcı, olumlu ve açık olması gerekmektedir (Ferguson, 2011). Bu çalışmada ÖÖY-II dersinde yapılan uygulamalar aracılığıyla katılımcıların etkili bir geri bildirimin özelliklerinin nasıl olması gerektiğinin farkına vardıklarını söylemek mümkündür. 
Kullanılması gereken değerlendirme yöntem/teknikleri ile ilgili katılımcıların görüşleri incelendiğinde, katılımcılar araştırma süreci boyunca geleneksel ve alternatif değerlendirme yöntem/tekniklerinin kullanılması gerektiğini belirttiler. Çalışmanın bu bulgusu Nazlıçiçek ve Akarsu (2008) tarafından yürütülen çalışmanın bulgularıyla farklılık göstermektedir. Çünkü Nazlıçiçek ve Akarsu (2008) öğretmenlerin alternatif değerlendirme tekniklerine güven duymadığını ve önem vermediğini belirlemiş̧lerdir. Bu çalışmada ise alternatif değerlendirme teknikleri, kimya öğretmen adayları tarafından hem ön testte hem de son testte kullanılması gereken teknikler olarak belirtildi. Buna rağmen geleneksel değerlendirme tekniklerinden biri olan açık uçlu soruların, kimya öğretmen adayları tarafından hem ön testte hem de son testte en çok ifade edilen değerlendirme tekniği olması dikkat çekici bir durumdur. Katılımcıların açık uçlu sorulara çok fazla yönelmelerinin sebebi; kavramsal anlamayı derinlemesine ve detaylarıyla değerlendirmek istemelerinden kaynaklı olabilir. Çalışmanın bu bulgusu Şen ve Nakiboğlu (2018) tarafından yürütülen çalışmanın bulgularıyla benzerlik göstermektedir. Güneş, Dilek, Hoplan, Çelikoğlu ve Demir (2010), fen bilgisi ve sınıf öğretmenleri ile yürüttüğü çalışmada, öğretmenlerin alternatif değerlendirme tekniklerini sıklıkla kullandıklarını ifade etmelerine rağmen, yapılan mülakatlarda ise bu tekniklerin nasıl uygulanacağını iyi bilmediklerini ifade ettiklerini tespit etmişlerdir. Bu çalışmada da katılımcılar tarafından hem ön testte hem son testte alternatif değerlendirme tekniklerinin kullanılması gerektiği belirtildi. Ancak katılımcıların bu yöntem/teknikleri uygulayabilme becerisi ve bu yöntem/teknikleri uygularken yaşayabilecekleri sorunlar bu çalışma kapsamında incelenmemiş olup, ileride yapılacak olan çalışmalarda bu noktanın incelenmesi önerilmektedir.

$\mathrm{Bu}$ çalışma kimya öğretmen adayları ile veri toplama aracı olarak tek bir test kullanılarak yürütüldü. Bu haliyle elde edilen bulgular tüm kimya öğretmen adayları için genellenebilir değildir. $\mathrm{Bu}$ durum çalışmanın bir sınırlılığıdır. İleride yapılacak olan çalışmalarda bu sınırlılığı ortadan kaldırmak için çeşitli veri toplama araçları kullanılarak veri çeşitlemesi sağlanması önerilmektedir. Ancak yine de bu çalışma sonuçları itibari ile bir ders dönemi süresinde kimya öğretmen adaylarının değerlendirmeye ilişkin bakış açılarının değişmesi ve çeşitlenmesi bakımından önemlidir. Öğretmenler üzerinde de benzer çalışmalar hizmet içi eğitim sürecinde yapılarak hem öğretmenlerin değerlendirmeye olan bakış açılarının tespit edilmesi hem de geliştirilmesi sağlanabilir. 


\title{
Makalenin Bilimdeki Konumu
}

\author{
Matematik ve Fen Bilimleri Eğitimi, Kimya Eğitimi Anabilim Dalı
}

\section{Makalenin Bilimdeki Özgünlüğü}

Bir kimya öğretmeninin öğretim yöntemleri bilgisi, öğrenci bilgisi, öğretim programı bilgisi, niçin ve nasıl kimya öğretilmeli bilgisinin yanında iyi bir değerlendirme bakış açısına sahip olması, uygulanan bir öğretim yöntem ve tekniğinin ne kadar etkili olduğunu, öğrencilerin istenilen kazanımlara ne oranda ulaştığının belirlenmesi ve alınan geri bildirimler doğrultusunda neler yapılabileceğini bilmesi eğitim-öğretim sürecinde kritik bir öneme sahiptir. Bu anlamda öğretmen adaylarının ve öğretmenlerin değerlendirmeye bakış açılarının geliştirilmesi eğitim-öğretim sürecindeki aksaklıkların düzenlenmesi ve giderilmesi açısından önemlidir. $\mathrm{Bu}$ çalışma, kimya öğretmen adaylarının değerlendirmeye bakış açılarının belirlenmesi ve değerlendirmenin eğitim-öğretim sürecinin önemli bir parçası olduğu konusunda farkındalık yaratılması aynı zamanda da değerlendirme kavramına ilişkin bakış açılarının öğretim uygulamaları yoluyla geliştirilmesi bakımından önemli katkılar sunmaktadir. 


\section{Kaynakça}

Bektas, O., Ekiz, B., Tuysuz, M., Kutucu, E. S., Tarkin, A. \& Uzuntiryaki-Kondakci, E. (2013). Preservice chemistry teachers' pedagogical content knowledge of the nature of science in the particle nature of matter. Chemistry Education Research and Practice, 14, 201-213.

Case, S. (2007). Reconfiguring and realigning the assessment feedback processes for an undergraduate criminology degree. Assessment \& Evaluation in Higher Education, 32(3), 285299.

Creswell, J. W. (2013). Research Design: Qualitative, Quantitative and Mixed Methods Approaches. London: Sage Publications.

DeLuca, C., Chavez, T. \& Cao, C. (2013). Establishing a foundation for valid teacher judgement on student learning: the role of pre-service assessment education. Assessment in Education: Principles, Policy \& Practice, 20(1), 107-126.

DeLuca, C. \& Klinger D. A. (2010). Assessment literacy development: identifying gaps in teacher candidates’ learning. Assessment in Education: Principles, Policy \& Practice, 17(4), 419-438.

Edwards, F. (2013). Quality assessment by science teachers: Five focus areas. Science Education International, 24(2), 212-226.

Ferguson, P. (2011). Student perceptions of quality feedback in teacher education. Assessment \& Evaluation in Higher Education, 36(1), 51-62.

Fraenkel, J. R. \& Wallen, N. E. (2006). How to design and evaluate in education. (6th ed.). New York: McGraw-Hill.

Friedrichsen, P., Lankford, D., Brown, P., Pareja, E., Volkmann, M. \& Abell, S. (2007). The PCK of future science teachers in an alternative certification program, National Association for Research in Science Teaching Annual Conference, New Orleans, LA.

Gelbal, S. ve Kelecioğlu, H. (2007). Öğretmenlerin ölçme ve değerlendirme yöntemleri hakkındaki yeterlik algıları ve karşılaştıkları sorunlar. Hacettepe Üniversitesi Eğitim Fakültesi Dergisi, 33, 135-145.

Graham, P. (2005). Classroom-based assessment: Changing knowledge and practice through preservice teacher education. Teaching and Teacher Education, 21, 607-621.

Grossman, P., Schoenfeld, A. H. \& Lee, C. (2005). Teaching subject matter. In L. Darling-Hammond \& J. D. Bransford (Eds.), Preparing teachers for a changing world: What teachers should learn and be able to do (pp. 201-231). San Francisco, CA: Jossey-Bass. 
Güneş, T., Dilek, N. Ş., Hoplan, M., Çelikoğlu, M. \& Demir, E. S. (2010). Öğretmenlerin alternatif değerlendirme konusundaki görüşleri ve yaptıkları uygulamalar. $1^{\text {st }}$ International Conference on New Trends in Education and Their Implications. 11-13 November, Antalya.

Hancock, E. \& Gallard, A. (2004), Preservice science teachers’ beliefs about teaching and learning: The influence of K-12 field experiences. Journal of Science Teacher Education, 15(4), 281291.

Izci, K. \& Caliskan, G. (2017). Development of prospective teachers’ conceptions of assessment and choices of assessment tasks. International Journal of Research in Education and Science (IJRES), 3(2), 464-474.

Karaman, P. ve Şahin, Ç. (2017). Öğretmen adaylarının ölçme-değerlendirme okuryazarlıklarının mikro-öğretim yoluyla geliştirilmesi. Turkish Studies-International Periodical For the Languages, Literature and History of Turkish or Turkic, 12(4), 255-274.

Lew, M. M. \& Nelson, R. F. (2016). New teachers’ challenges: How culturally responsive teaching, classroom management, \& assessment literacy are intertwined. Multicultural Education, 7-13.

Linn, R. L. \& Gronlund, N. E. (1995). Measurement and assessment in teaching. (7th ed.) New Jersey: Prentice Hall.

Magnusson, S., Krajcik, J. \& Borko, H. (1999). Nature, sources and development of pedagogical content knowledge for science teaching. In J. Gess-Newsome and N. G. Lederman (Eds.), Examining pedagogical content knowledge (pp. 95-132). Dordrecht, The Netherlands: Kluwer Academic.

McConnell, K. D. \& Doolittle, P. E. (2012). Classroom-level assessment: Aligning pedagogical practices to enhance student learning. In C. Secolsky and D. B. Denison (Eds.), Handbook on measurement, assessment, and evaluation in higher education (pp.15-30). New York: Routledge.

Mertler, C. A. (2009). Teachers' assessment knowledge and their perceptions of the impact of classroom assessment professional development. Improving Schools, 12(2), 101-113.

Metin, M. ve Özmen, H. (2010). Biçimlendirici değerlendirmeye yönelik öğretmen adaylarının düşünceleri. Milli Ĕgitim Dergisi, 187, 293-310.

Milli Eğitim Bakanlığı (MEB). (2018). Ortaöğretim Kimya Dersi Öğretim Programı. http://mufredat.meb.gov.tr/ProgramDetay.aspx?PID=350 adresinden alınmıştır.

Nazlıçiçek, N. ve Akarsu, F. (2008). Fizik, kimya ve matematik öğretmenlerinin değerlendirme araçlarıyla ilgili yaklaşımları ve uygulamaları. Eğitim ve Bilim, 33(149), 18-29. 
OECD (2014), “Indicator D4: How much time do teachers spend teaching?”, in Education at a Glance 2014: OECD Indicators, OECD Publishing. http://dx.doi.org/10.1787/888933120005

Patton, M. Q. (2014). Nitel araştırma ve değerlendirme yöntemleri (M. Bütün ve S. B. Demir, Çev.). Ankara: Pegem Akademi.

Rowntree, D. (2015). Assessing students: How shall we know them?. London: Routledge.

Shulman, L. S. (1986). Those who understand: Knowledge growth in teaching. Educational Researcher, 15(2), 4-14.

Şad, S. N. ve Göktaş, Ö. (2013). Öğretim elemanlarının geleneksel ve çağdaş ölçme değerlendirme yaklaşımlarının incelenmesi. Ege Ĕgitim Dergisi, 14(2), 79-105.

Şen, A. Z. ve Nakiboğlu, C. (2018). Deneyimli kimya öğretmenlerinin alan eğitimi bilgisi temelinde ölçme bilgilerinin fiziksel-kimyasal değişimler konusu kapsamında belirlenmesi. Necatibey Ĕ̈itim Fakültesi Elektronik Fen ve Matematik Eğitimi Dergisi, 12(2), 698-726.

Tacoshi, M. M. A. \& Fernandez, C. (2014). Knowledge of assessment: An important component in the PCK of chemistry teachers. Problems of education in the 21st century, 62, 124-147.

Tamir, P. (1988). Subject matter and related pedagogical knowledge in teacher education. Teaching and Teacher Education, 4(2), 99-110.

Taşdemir, M. ve Taşdemir, F. (2016). Ölçme ve değerlendirme uygulamaları hakkında öğretmen adayı görüşlerinin metafor yoluyla analizi. Turkish Studies: International Periodical for the Languages, Literature and History of Turkish or Turkic, 11(9), 775-802.

Tatar, N. and Buldur, S. (2013). Improving preservice science teachers' self-efficacy about the use of alternative assessment: Implication for theory and practice. Journal of Baltic Science Education, 12(4), 452-464.

Tünkler, V. ve Güven, C. (2019). Mikroöğretim uygulamasının öğretmen adaylarının tamamlayıcı ölçme-değerlendirme tekniklerine yönelik okuryazarlık düzeylerine etkisi. Hacettepe Üniversitesi Eğitim Fakültesi Dergisi, 34(2), 541-564.

Uğurlu, R. ve Akkoç, H. (2011). Matematik öğretmen adaylarının ölçme-değerlendirme bilgilerinin gelişiminin tamamlayıcı-şekillendirici ölçme-değerlendirme bağlamında incelenmesi. Pamukkale Üniversitesi Eğitim Fakültesi Dergisi, 30(30), 155-167.

Volante, L. \& Fazio, X. (2007). Exploring teacher candidates’ assessment literacy: Implications for teacher education reform and professional development. Canadian Journal of Education, 30(3), 749-770.

Zainal, Z. (2007). Case study as a research method. Jurnal Kemanusiaan, 9, 1-6. 


\section{Summary}

Problem Statement: Teachers should know what to focus on in order to assess their students' learning and development meaningfully and beneficially (Edwards, 2013). Assessing students and making inferences about them, making instruction-related decisions and improving their comprehension and thinking skills constitute the main purposes of assessment. It is difficult for teachers to do assessment for an accurate goal by using appropriate assessment techniques at the right time (Friedrichsen et al., 2007). Training teachers how to do assessment is a necessity for improving the quality of education (Volante and Fazio, 2007). Teacher education programs play a large role in pre-service teachers' approach for learning and assessment. These programs are also of critical importance for assessment literacy and training teachers to learn about assessment throughout their professional lives (DeLuca, Chavez and Cao, 2013). Assessment is one of the tough processes teachers encounter in their classrooms (Lew and Nelson, 2016). In order to cope with it, pre-service teachers' experiences with assessment should be increased, and they should be provided with opportunities for professional development (Tatar and Buldur, 2013). However, it is clear that the studies in the literature have not addressed assessment in this context. Therefore, this study is thought to contribute to the literature. It investigated pre-service chemistry teachers' perspectives on assessment and the change in these perspectives after the practices in the course of Chemistry Teaching Methods-II (CTM-II).

Purpose of the study: This study aimed to determine the pre-service chemistry teachers' perspectives on the concept of assessment and the change in their perspectives after the practices during the CTM-II course.

Method: This is a case study with a qualitative approach. Its voluntary participants were 13 third grade pre-service teachers from the chemistry education department of a state university. The pre-test and post-test used seven open-ended questions to determine their perspectives on assessment based on their written responses. At the beginning of the study, the participants designed and performed lesson plans for 40-minute lessons about chemistry topics. The researchers did not intervene in this process. After all participants performed one lesson, the researchers provided information about the teaching methods and techniques commonly used in chemistry education, pedagogical content knowledge and assessment. Following this process, the participants designed and performed two more lesson plans on the topic they 
initially selected. The participants' pre- and post-test responses were analyzed using content analysis.

Findings and Discussions: This study investigated the pre-service teachers' perspectives on assessment and found that their perspectives changed as a result of the practices in the CTMII course. Before the CTM-II course, the participants perceived assessment as a result-oriented process indicating the level of attainment of objectives. However, after the course, their definitions of assessment become more diverse. Despite the participants who still considered assessment to be result-oriented, an increase in the number of the participants who considered assessment an inseparable part of lessons and thought of use assessment for diagnosis and evaluating their own teaching was found on the post-test. After the CTM-II course, the participants, who prior to this course thought that assessment should be carried out "at odd moments," "at the end of the topic" or "at the end of the lesson," said that assessment should be extended throughout the entire lesson. Initially, the fact that teachers should assess conceptual understanding was the point expressed most frequently by the participants. However, after the CTM-II course, it was determined that they think of assessing not only cognitive objectives, but also affective objectives such as interest, attitude, and motivation. A clear change was found in the participants' perspectives concerning the time needed for assessment. While the participants had a wide range of perspectives concerning this time before the practices in the CTM-II course, after these practices, they adopted a common perspective that it should be extended throughout the entire lesson. Both before and after the practices, the participants agreed that students should be provided with feedback on the results of the assessments. Before the CTM-II course, the participants did not include any details about the quality of the feedback to be provided. After the CTM-II course, they said that feedback should motivate students. Throughout the study, the participants indicated that traditional and alternative assessment methods and techniques should be used.

Conclusion and Recommendations: This study caused changes in the pre-service chemistry teachers' perspectives on assessment thanks to the practices in the CTM-II course. It considerably contributes to the literature by determining pre-service chemistry teachers' perspectives on assessment, raising their awareness that assessment is an essential component of education and improving perspectives on assessment through teaching practices. It is important to improve pre-service teachers' perspectives on assessment in order to organize and 
YYÜ Eğitim Fakültesi Dergisi (YYU Journal of Education Faculty), 2019; 16(1):1698-1728, http://efdergi.yyu.edu.tr

eliminate problems in education. Similar studies can be conducted with teachers in in-service training to determine and improve their perspectives on assessment.

Keywords: Chemistry education, pre-service chemistry teacher, perspectives on assessment 